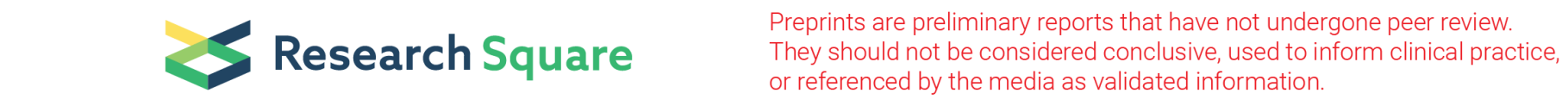

\title{
COVID-19 Mortality in Malaria Endemic Countries: An Ecological Study
}

Michael, U. Anyanwu ( $\sim$ mustil4god@gmail.com )

Mbarara University of Science and Technology

\section{Research Article}

Keywords: Covid-19, Mortality, Malaria, Endemic, Ecological study.

Posted Date: February 4th, 2021

DOI: https://doi.org/10.21203/rs.3.rs-152325/v1

License: (c) (i) This work is licensed under a Creative Commons Attribution 4.0 International License. Read Full License 


\section{Abstract}

\section{Introduction}

The number of persons infected with COVID-19 continue to increase with deaths reported daily across the globe. High income countries such as the US, the UK, Italy and Belgium have reported high COVID-19 related deaths but low-andmiddle-income countries have recorded fewer deaths despite having poor healthcare system. This study aimed to investigate the association between malaria prevalence and COVID-19 mortality.

\section{Methods}

This is an ecological study with data from 195 countries. Spearman's correlation was used to test the association between the population variables and COVID-19 mortality. Generalized linear model with Poisson distribution was used to determine the significant predictors of COVID-19 mortality.

\section{Results}

There was a significant positive correlation between median age, life expectancy, 65+ mortality and COVID-19 mortality while malaria prevalence, sex ratio and cardiovascular mortality were negatively correlated with COVID-19 mortality. Malaria prevalence, life expectancy and mortality rate were significant on multivariate regression analysis.

\section{Conclusion}

The results of this study support the hypotheses that there is reduced COVID-19 deaths in malaria endemic countries, although the results need to be proved further by clinical trials.

\section{Introduction}

Coronavirus disease 2019 (COVID-19) is an infectious disease which is caused by a new coronavirus known as SARSCoV-2 (Severe Acute Respiratory Syndrome Coronavirus 2) (1). The outbreak began in Hubei province of China in December 2019, and it was announced as a Public Health Emergency of International Concern on January 2020, and later on March 2020, proclaimed a pandemic by the World Health Organization (WHO) after more than 4291 deaths were recorded in many countries (2). COVID-19 is transmitted through close contact with infected droplets from sneezing, coughing, talking or breathing (3). The signs and symptoms includes fever or chills, cough, shortness of breath or difficulty in breathing, fatigue, headaches, new loss of taste or smell, sore throat among others (3). Hand hygiene, social distancing, isolation and use of face masks have been recommended by WHO as well as other preventive measures such as local and international travel restrictions and lockdowns in order to stop the spread of COVID-19 (4).

As at December 25, 2020, there were about 1,736,752 COVID-19 related deaths reported globally (5). In various countries, differences in COVID-19 mortality has been observed with most Western countries having high mortality per million populations (6). For example, the mortality per million populations in the USA is 977, the United Kingdom (1025), France (948) and Belgium (1642). However, in developing nations, low COVID-19 mortality have been reported with Nigeria having a mortality per million populations of 6, Kenya (30), India (106) and Venezuela (35). This is in contrast to what was speculated in low-and-middle income countries where the morbidity and mortality of COVID-19 was expected to be high compared to Western countries (7). Epidemiological studies have identified several factors associated with COVID-19 mortality. A study reported that the mean age, life expectancy and other population characteristics in African countries account for the low COVID-19 mortality (8). Another ecological study of COVID-19 mortality across 173 countries showed that median age of the population and life expectancy were associated with COVID-19 mortality (6). Pre-existing conditions have also been found to be associated with COVID-19 deaths. The Chinese Centre for Disease Control and 
Prevention reported in a study that cardiovascular disease, diabetes, hypertension and cancers were associated with an increased risk of covid-19 death (9).

There has been widespread speculation that hydroxychloroquine a drug used to treat malaria can be used to prevent and treat COVID-19. Although some studies reported that it may inhibit COVID-19 virus, other studies showed that it has no positive effect on COVID-19. Scientists have argued that its use in some countries is responsible for the low COVID-19 deaths in those countries, and studies conducted during the early period of the pandemics revealed that there is reduced spread of COVID-19 in malaria endemic countries (10). Following this assumption, the hypotheses that immune response against malaria in malaria endemic countries may have protective effects against COVID-19 was proposed.

\section{Materials And Methods}

\section{Study Design}

This is an ecological study which compared population variables of 195 countries.

\section{Data Resources}

All data were obtained from open resources. Information on COVID-19 was obtained from the WHO Coronavirus Disease Situation Dashboard (5). Malaria data was obtained from the World Malaria Report 2020 (11). All data regarding the population variables were obtained from the United Nations database (12), and data regarding cardiovascular mortality rate was culled from 'Our World in Data' (13).

\section{Dependent Variable}

The dependent variable evaluated in this study was COVID-19 mortality (total COVID-19 related deaths per million population) in each county obtained from the WHO Coronavirus Disease Situation Dashboard on 25th December, 2020 (5).

\section{Independent Variable}

Malaria prevalence was converted to total malaria cases per million population in each country. The data on malaria morbidity was culled from the World Malaria Report 2020 (11).

\section{Covariates}

The covariates assessed in this study were median age, life expectancy at birth, mortality rate per 1000 population, $65+$ mortality rate, sex ratio and cardiovascular mortality per 100,000 obtained from the United Nations database and 'Our World in Data' $(12,13)$.

\section{Statistical Analysis}

STATA Version 12 was used for all statistical analysis. Spearman's correlation was used to test the association between COVID-19 mortality and the population variables. Generalized linear model (GLM) with Poisson distribution and log link was used to determine the significant predictors of COVID-19 mortality rate (deaths per million population). The Generalized linear model was used by reason of the zero values and non-parametric distribution of the dependent variable.

\section{Ethics Approval}


Approval from institutional review board was not sought for this study due to the use of publicly available data from open resources.

\section{Results}

A total of 195 countries that have data on COVID-19 deaths, malaria cases and population variables were included in the study. Table 1 and Table 2 shows the countries with the highest and lowest COVID-19 deaths per million populations and their population characteristics. Belgium (1643), Slovenia (1212), Bosnia and Herzegovina (1182) and Italy (1173) have the highest COVID-19 deaths per million population while Samoa (0), Turkmenistan (0) and Seychelles are among the countries with no COVID-19 mortality. Among malaria endemic countries, Benin (391065), Burkina Faso (371174), Liberia (353937) and Rwanda (352794) have the highest malaria cases per million population.

Table 1

Population Characteristics of Countries with Highest COVID-19 Mortality Per Million Population

\begin{tabular}{|c|c|c|c|c|c|c|c|c|}
\hline Country & $\begin{array}{l}\text { Covid } \\
\text { Deaths }\end{array}$ & $\begin{array}{l}\text { Malaria } \\
\text { Prevalence }\end{array}$ & $\begin{array}{l}\text { Median } \\
\text { Age }\end{array}$ & $\begin{array}{l}\text { Sex } \\
\text { Ratio }\end{array}$ & $\begin{array}{l}\text { Life } \\
\text { Expectancy }\end{array}$ & $\begin{array}{l}\text { Mortality } \\
\text { Rate }\end{array}$ & $\begin{array}{l}65+ \\
\text { Mortality }\end{array}$ & $\begin{array}{l}\text { CVD } \\
\text { Mortality }\end{array}$ \\
\hline Belgium & 1643 & 0 & 42 & 98 & 81 & 10 & 84 & 114 \\
\hline Slovenia & 1212 & 0 & 45 & 99 & 81 & 10 & 83 & 153 \\
\hline $\begin{array}{l}\text { Bosnia and } \\
\text { Herzegovina }\end{array}$ & 1182 & 0 & 43 & 96 & 77 & 11 & 78 & 329 \\
\hline Italy & 1173 & 0 & 47 & 95 & 83 & 11 & 89 & 113 \\
\hline $\begin{array}{l}\text { North } \\
\text { Macedonia }\end{array}$ & 1140 & 0 & 39 & 100 & 76 & 10 & 77 & 322 \\
\hline Peru & 1129 & 1378 & 31 & 99 & 76 & 6 & 60 & 85 \\
\hline Spain & 1066 & 0 & 45 & 97 & 83 & 9 & 86 & 99 \\
\hline Montenegro & 1033 & 0 & 39 & 98 & 77 & 11 & 79 & 387 \\
\hline UK & 1026 & 0 & 41 & 98 & 81 & 9 & 84 & 122 \\
\hline Czechia & 1014 & 0 & 43 & 97 & 79 & 11 & 82 & 227 \\
\hline Bulgaria & 1011 & 0 & 45 & 94 & 75 & 15 & 79 & 424 \\
\hline USA & 977 & 0 & 38 & 98 & 79 & 9 & 74 & 151 \\
\hline France & 948 & 0 & 42 & 94 & 82 & 9 & 84 & 86 \\
\hline Argentina & 936 & 0 & 31 & 95 & 76 & 8 & 72 & 191 \\
\hline Mexico & 933 & 5 & 29 & 96 & 75 & 6 & 57 & 152 \\
\hline
\end{tabular}


Table 2

Population Characteristics of Countries with Lowest COVID-19 Mortality Per Million Population

\begin{tabular}{|c|c|c|c|c|c|c|c|c|}
\hline Country & $\begin{array}{l}\text { Covid } \\
\text { Deaths }\end{array}$ & $\begin{array}{l}\text { Malaria } \\
\text { Prevalence }\end{array}$ & $\begin{array}{l}\text { Median } \\
\text { Age }\end{array}$ & $\begin{array}{l}\text { Sex } \\
\text { Ratio }\end{array}$ & $\begin{array}{l}\text { Life } \\
\text { Expectancy }\end{array}$ & $\begin{array}{l}\text { Mortality } \\
\text { Rate }\end{array}$ & $\begin{array}{l}65+ \\
\text { Mortality }\end{array}$ & $\begin{array}{l}\text { CVD } \\
\text { Mortality }\end{array}$ \\
\hline Vanuatu & 0 & 3371 & 21 & 103 & 70 & 5 & 54 & 546 \\
\hline Tonga & 0 & 0 & 22 & 100 & 71 & 7 & 61 & 227 \\
\hline Grenada & 0 & 0 & 32 & 102 & 72 & 10 & 68 & 243 \\
\hline North Korea & 0 & 186 & 35 & 96 & 72 & 9 & 65 & 321 \\
\hline $\begin{array}{l}\text { St. Vincent \& the } \\
\text { Grenadines }\end{array}$ & 0 & 0 & 33 & 103 & 72 & 9 & 63 & 252 \\
\hline Micronesia & 0 & 0 & 24 & 103 & 68 & 7 & 47 & 454 \\
\hline Samoa & 0 & 0 & 22 & 107 & 73 & 5 & 60 & 348 \\
\hline Laos & 0 & 1434 & 24 & 101 & 67 & 7 & 41 & 368 \\
\hline Solomon Island & 0 & 236540 & 20 & 104 & 73 & 4 & 44 & 459 \\
\hline Turkmenistan & 0 & 0 & 27 & 97 & 67 & 7 & 40 & 536 \\
\hline Timor-Leste & 0 & 0 & 21 & 102 & 69 & 6 & 46 & 335 \\
\hline Seychelles & 0 & 0 & 34 & 105 & 73 & 8 & 58 & 242 \\
\hline Mongolia & 0 & 0 & 28 & 97 & 70 & 6 & 40 & 460 \\
\hline Bhutan & 0 & 3 & 28 & 113 & 71 & 6 & 44 & 217 \\
\hline Cambodia & 0 & 8323 & 26 & 95 & 69 & 6 & 44 & 270 \\
\hline
\end{tabular}

COVID-19 mortality per million population has a significant negative correlation with malaria prevalence $(r=-0.459, p<$ $0.001)$, cardiovascular deaths per $100,000(r=-0.310, p<0.001)$ and sex ratio $(-0.219, p=0.003)$. There was a significant positive correlation between COVID-19 mortality and median age $(r=0.595, p<0.001)$, life expectancy $(r=0.582, p<0.001)$ and $65+$ mortality rate $(r=0.583, p<0.001)$. Details are shown in Table 3 .

Malaria prevalence and all the covariates were significant in bivariate analysis, however, multivariate analysis showed that malaria prevalence $(p<0.001 ; \mathrm{Cl}=0.99-0.99)$, mortality rate $(\mathrm{p}=0.006 ; \mathrm{Cl}=1.06-1.46)$ and life expectancy $(p=$ $0.021 ; \mathrm{Cl}=1.02-1.29)$ were significantly associated with COVID-19 mortality. Details of the regression analysis are shown in Table 4. 
Table 3

Spearman's Correlation of COVID-19 Mortality, Malaria Prevalence and Population Variables

\begin{tabular}{|c|c|c|c|c|c|c|c|c|c|c|}
\hline Variables & & $\begin{array}{l}\text { Covid } \\
\text { Cases }\end{array}$ & $\begin{array}{l}\text { Covid } \\
\text { Deaths }\end{array}$ & $\begin{array}{l}\text { Malaria } \\
\text { Prevalence }\end{array}$ & $\begin{array}{l}\text { Median } \\
\text { Age }\end{array}$ & $\begin{array}{l}\text { Sex } \\
\text { Ratio }\end{array}$ & LE & $\begin{array}{l}\text { Mortality } \\
\text { Rate }\end{array}$ & $\begin{array}{l}65+ \\
\text { Mortality }\end{array}$ & $\begin{array}{l}\text { CVD } \\
\text { Mortality }\end{array}$ \\
\hline \multirow{2}{*}{$\begin{array}{l}\text { Covid } \\
\text { Cases }\end{array}$} & $\mathrm{R}$ & 1 & & & & & & & & \\
\hline & $p$ & & & & & & & & & \\
\hline \multirow{2}{*}{$\begin{array}{l}\text { Covid } \\
\text { Deaths }\end{array}$} & $\mathrm{R}$ & 0.929 & 1 & & & & & & & \\
\hline & $p$ & 0.000 & & & & & & & & \\
\hline \multirow{2}{*}{$\begin{array}{l}\text { Malaria } \\
\text { Prevalence }\end{array}$} & $\mathrm{R}$ & -0.544 & -0.459 & 1 & & & & & & \\
\hline & $p$ & 0.000 & 0.000 & & & & & & & \\
\hline \multirow{2}{*}{$\begin{array}{l}\text { Median } \\
\text { Age }\end{array}$} & $\mathrm{R}$ & 0.660 & 0.595 & -0.775 & 1 & & & & & \\
\hline & $\mathrm{p}$ & 0.000 & 0.000 & 0.000 & & & & & & \\
\hline \multirow[t]{2}{*}{ Sex Ratio } & $\mathrm{R}$ & -0.219 & -0.279 & 0.144 & -0.317 & 1 & & & & \\
\hline & $\mathrm{p}$ & 0.003 & 0.000 & 0.050 & 0.000 & & & & & \\
\hline \multirow{2}{*}{$\begin{array}{l}\text { Life } \\
\text { Expectancy }\end{array}$} & $\mathrm{R}$ & 0.644 & 0.582 & -0.744 & 0.860 & -0.118 & 1 & & & \\
\hline & $p$ & 0.000 & 0.000 & 0.000 & 0.000 & 0.109 & & & & \\
\hline \multirow{2}{*}{$\begin{array}{l}\text { Mortality } \\
\text { Rate }\end{array}$} & $\mathrm{R}$ & 0.115 & 0.141 & -0.009 & 0.283 & -0.494 & -0.080 & 1 & & \\
\hline & $p$ & 0.119 & 0.056 & 0.908 & 0.000 & 0.000 & 0.281 & & & \\
\hline \multirow{2}{*}{$\begin{array}{l}65+ \\
\text { Mortality }\end{array}$} & $\mathrm{R}$ & 0.635 & 0.583 & -0.790 & 0.925 & -0.274 & 0.913 & 0.192 & 1 & \\
\hline & $\mathrm{p}$ & 0.000 & 0.000 & 0.000 & 0.000 & 0.000 & 0.000 & 0.009 & & \\
\hline \multirow{2}{*}{$\begin{array}{l}\text { CVD } \\
\text { Mortality }\end{array}$} & $\mathrm{R}$ & -0.333 & -0.310 & 0.192 & -0.385 & 0.063 & -0.586 & 0.104 & -0.432 & 1 \\
\hline & $\mathrm{p}$ & 0.000 & 0.000 & 0.009 & 0.000 & 0.398 & 0.000 & 0.161 & 0.000 & \\
\hline
\end{tabular}

Table 4

Regression Analysis of Predictors of COVID-19 Mortality

\begin{tabular}{|c|c|c|c|c|c|c|}
\hline \multirow[t]{2}{*}{ Variable } & \multicolumn{3}{|c|}{ Crude } & \multicolumn{3}{|c|}{ Adjusted } \\
\hline & IRR & $p$ value & $95 \% \mathrm{Cl}$ & IRR & p value & $95 \% \mathrm{Cl}$ \\
\hline Median Age & 1.09 & $<0.001$ & $1.07-1.11$ & 0.96 & 0.238 & $0.90-1.03$ \\
\hline Sex Ratio & 0.99 & 0.035 & $0.97-0.99$ & 1.00 & 0.939 & $0.99-1.01$ \\
\hline Life Expectancy & 1.13 & $<0.001$ & $1.10-1.15$ & 1.14 & 0.021 & $1.02-1.29 *$ \\
\hline Mortality Rate & 1.12 & $<0.001$ & $1.06-1.18$ & 1.24 & 0.006 & $1.06-1.46^{\star \star}$ \\
\hline $65+$ Mortality & 1.04 & $<0.001$ & $1.03-1.05$ & 0.99 & 0.687 & $0.96-1.03$ \\
\hline CVD Mortality & 0.99 & $<0.001$ & $0.99-0.99$ & 0.99 & 0.253 & $0.99-1.00$ \\
\hline Malaria Prevalence & 0.99 & $<0.001$ & $0.99-0.99$ & 0.99 & $<0.001$ & $0.99-0.99 * \star *$ \\
\hline
\end{tabular}

IRR = Incidence Rate Ratio 


\section{Discussion}

This ecological study aimed to determine the association between COVID-19 mortality and malaria prevalence. After adjusting for the population dynamics, malaria prevalence was significantly associated with COVID-19 mortality. The results of this study is consistent with previous studies which revealed that malaria endemic countries have reduced COVID-19 morbidity and mortality $(10,14,15)$.

The association between COVID-19 and malaria prevalence could be as a result of immune response against malaria in malaria endemic countries, and the extensive use of chloroquine drugs and its derivatives. Several studies have revealed that it is plausible to have cross immunity, where one pathogen can provide immunity against another pathogen $(16,17)$. For example, prior exposure to Plasmodium has been shown to have protective effects against Chikungunya (18). Studies have discovered that SARS-CoV-2 uses the angiotensin-converting enzyme 2 (ACE2) receptor to invade the host cells (19). Similarly, studies have revealed that ACE1 and ACE2 polymorphisms protects the host from susceptibility to malaria (20, 21). Furthermore, studies have indicated that interferons generated by lymphocytes as an immune response to malaria have in vitro and in vivo efficacy against the coronavirus responsible for COVID-19 $(22,23)$. The therapeutic role of chloroquine and its derivatives in COVID-19 infection remains unclear. Although, studies have reported the antiviral and anti-inflammatory role of these drugs, however, clinical trial is still ongoing with early results showing no difference between these drugs and standard care (24-27). The relationship between malaria and COVID-19 is complicated considering that malaria and COVID-19 have common symptoms, despite the fact that COVID-19 is more aggressive in adults while malaria affects more children (28).

There are several limitations to this study. First, this is an ecological study and the outcome is limited with a high potential of bias. Second, the effect of lock downs, restriction of internal and international movement, restriction of public gatherings and public events, healthcare systems and other population covariates were not adjusted in this study. Third, the COVID-19 pandemics is still ongoing and the results may be different few months from now.

\section{Conclusion}

The results of this study support the hypotheses that there is reduced COVID-19 deaths in malaria endemic countries. Given the evidence from this ecological study, it may worth conducting laboratory experiments and clinical trials in order to validate the results of this study.

\section{Declarations}

\section{Ethics approval and consent to participate}

Approval from institutional review board was not sought for this study due to the use of publicly available data from open resources.

\section{Consent for publication}

Not Applicable

\section{Availability of data and materials}

The datasets used and/or analyzed during this study are available from the corresponding author on reasonable request.

\section{Competing Interests}

The authors declare that they have no competing interests. 


\section{Authors' Contributions}

AMU was the sole author involved in the conceptualization, data collection, and writing of this article.

\section{Funding}

None

\section{Acknowledgement}

None

\section{References}

1. WHO. Coronavirus. 2020 [cited 2021 January]; Available from: www.who.int/health-topics/coronavirus.

2. WHO. WHO Director-General's opening remark at the media briefing on COVID-19. 2020 [cited 2021 January]; Available from: www.who.int/director-general-s-opening-remarks-at-the-media-briefing-on-covid-19-11-march-2020.

3. Centers for Disease Control and Prevention C. Covid-19. 2020 [cited 2021]; Available from: www.cdc.gov/coronavirus/2019-ncov/prevent-getting-sick/how-covid-spreads.html.

4. World Health Organization W. Coronavirus Disease. 2021 [cited 2021]; Available from: www.who.int/emergencies/diseases/novel-coronavirus-2019/advice-for-public.

5. World Health Organisation W. Covid-19. 2020 [cited 2020]; Available from: https://covid19.who.int/table.

6. Mitsuyoshi U, Katharina O, Yasutaka H, Taisuke A. BCG Vaccination and Mortality of COVID-19 across 173 Countries: An Ecological Study. International journal of Environment Research and Public Health. 2020;17(5589).

7. Murray CJ, Lopez AD, Chin B, Feehan D, Hill KH. Estimation of potential global pandemic influenza mortality on the basis of vital registry data from the 1918-20 pandemic: A quantitative analysis. Lancet. 2006;368(2211-2218).

8. Yakubu L. Africa's Low COVID-19 Mortality Rate: A paradox. International Journal of Infectious Diseases. 2020;102:118-22.

9. Deng G, Yin M, Chen X, Zeng F. Clinical determinants for fatality of 44,672 patients with COVID-19 Crit care. 2020;179.

10. Azhar M, Kiran K, Manish T, Rupesh S, Asif M. Comparative analysis revealed reduced spread of COVID-19 in malaria endemic countries. medRxiv. 2020.

11. World Health Organization W. World malaria report 2020: 20 years of global progress and challenges. Geneva2020.

12. United Nations. UN World Population Prospects. 2020 [cited 2021 January 2]; Available from: https://data.un.org.

13. Our world in Data. Cardiovascular diseases. 2018 [cited 2021 January 7]; Available from: https:ourworldindata.org/grapher/cardiovascular-disease-death-rates?tab.

14. Hussein MIH, Albashir AAD, Elawed OAMA. Malaria and COVID-19: unmasking their ties. Malaria Journal. 2020;19(457).

15. Pietro EN, Matteo N. Global spread of coronavirus disease 2019 and malaria: An epidemiological paradox in the early stage of a pandemic. Journal of clinical medicine. 2020;8(4).

16. Schofield L, Mueller I. Clinical immunity to malaria. Curr Mol Med. 2006;6(2).

17. Bustinduy AL, et al. Age strattified profiles of serum IL-6, IL-10, and TNF-alpha cytokines among Kenyan children with schistosoma haematobium, plasmodium falciparum and other chronic parasitic co-infections. Am J Trop Med Hyg. 2015;95(5).

18. Teo TH, et al. Plasmodium co-infection protects against chikungunya virus induced pathogies. Nat Commun. 2018;2018(9):1 
19. Hoffmann M, Kleine-Weber H, Kruger N, Muller M, Drosten C, Pohlmann S. The novel coronavirus 2019 uses the SARScoronavirus receptor ACE2 and the cellular protease TMPRSS2 for entry into target cells. bioRxiv. 2020.

20. Rasti N, Wahlgren M, Chen Q. Molecular aspects of malaria pathogenesis. FEMS ImmunolMed Microbiol. $2004 ; 41$.

21. Dhangadamajhi G, Mohapatra BN, Kar SN, Ranjit M. Gene polymorphisms in angiotensin 1 converting enzyme (ACE1/D) and angiotensin 2 converting enzyme (ACE2) protect against cerebral malaria in Indian adults. Infect Genet Evol. 2010;10:337-41.

22. Strayer D, Dickey R, Carter W. Sensitivity of SARS/MERS CoV to interferons and other drugs based on achievable serum concentrations in humans. Infect Disord Drug Targets. 2014;14:37-43.

23. Fauci AS, Lane HC, Redfield RR. COVID-19 - navigating the uncharted. N Engl J Med. 2020;382:1268-9.

24. Boulware DR, Pullen MF, Bangdiwala AS, Pastick KA, Lofgren SM, Okafor EC, et al. A randomized trial of hydroxychloroquine as postexposure prophylaxis for COVID-19. N Engl J Med. 2020;383:517-25.

25. NIAIDS. Evaluating the efficacy of hydroxychloroquine and azithromycin to prevent hospitalization or death in persons with COVID-19. [cited 2020]; Available from: https://clinicaltrials.gov/ct2/show/NCT04358068.

26. Savarino A, Boelaert JR, Cassone A, Majori G, Cauda R. Effects of chloroquine on viral infections: an old drug against today's diseases. Lancet Infect Dis. 2003;3(722-7).

27. Vincent MJ, Bergeron E, Benjannet S, Erickson BR, Rollin PE, Ksiazek TG. Chloroquine is a potent inhibitor of SARS coronavirus infection and spread. Virol J. 2005;2(69).

28. Francesco DG, Claudia M, Pietro L, Damiano P, Giovanni P. Malaria and COVID-19: common and different findings. Trop Med Infect Dis. 2020;5(141). 